\title{
ANALISIS PENGARUH PAJAK DAERAH, RETRIBUSI DAERAH, DAN PDRB TERHADAP KESEJAHTERAAN MASYARAKAT
}

\author{
Ari Nurul Fatimah ${ }^{1}$, Diah Agustina Prihastiwi ${ }^{2}$, Vita Irawati ${ }^{3}$ \\ Program Studi Akuntansi, Fakultas Ekonomi, Universitas Tidar \\ 1ari.nurul.fatimah@untidar.ac.id \\ 22diahprihastiwi@untidar.ac.id \\ 3 vitairawati2201@gmail.com
}

\begin{abstract}
Abstrak
Penelitian ini bertujuan untuk menganalis pengaruh pajak daerah, retribusi daerah, dan PDRB terhadap kesejahteraan masyarakat. Populasi pada penelitian ini yaitu 29 kabupaten dan 6 kota di Provinsi Jawa Tengah pada periode 2015-2019. Metode peneltian ini yaitu penelitian kuantitatif dengan data sekunder. Data penelitian diambil dari website resmi Badan Pusat Statistik Provinsi Jawa Tengah dan website resmi DJPK Kemenkeu. Metode analisis dalam penelitian ini menggunakan regresi liner berganda. Hasil penelitian menunjukkan bahwa variabel pajak daerah, retribusi daerah, dan PDRB berpengaruh signifikan terhadap kesejahteraan masyarakat di Provinsi Jawa Tengah.
\end{abstract}

Kata Kunci : Pajak Daerah, Retribusi Daerah, PDRB, IPM

\section{Abstract}

This study aims to analyze the effect of local taxes, regional levies, and GRDP on public welfare. The population in this study were 29 districts and 6 cities in Central Java Province in the 2015-2019 period. This research method is quantitative research with secondary data. The research data was taken from the official website of the Central Statistics Agency of Central Java Province and the official website of the Ministry of Finance DGT. The analytical method in this study uses multiple linear regression. The results showed that the variables of local taxes, regional levies, and GRDP significantly influence the welfare of the people in Central Java Province.

Keyword: local taxes, regional levies, GRDP, IPM

\section{PENDAHULUAN}

\subsection{Latar Belakang}

Otonomi daerah yang ada di Indonesia telah diprioritaskan pada kewenangan daerah kabupaten dan daerah kota. Kewenangan tersebut dimulai dari kewenangan atas dasar pembiayaan atau pendapatan yang diterima oleh daerah kebupaten dan kota. Kemampuan daerah dalam memanfatkan pembaiayaan yang diberikan oleh pemerintah pusat merupakan 
suatu keberhasilan yang dapat dicapai oleh setiap daerah. Pembiayaan yang diperoleh oleh pemerintah daerah tersebut berupa Anggaran Pendapatan dan Belanja Daerah (APBD) (Riduansyah, 2003).

Anggaran Pendapatan dan Belanja Daerah (APBD) menjadi salah satu bagian terpenting dalam pelaksanaan infrastruktur daerah. Pengelolaan APBD dilaksanakan secara transparan, akuntabel, efektif dan efisien suapaya daapat dipertanggungjawabkan secara sosial. Salah satu komponen APBD yang penting dalam upaya pembangunan daerah yaitu penerimaan daerah. Penerimaan dalerah terdiri dari pajak daerah, retribusi daerah, laba usaha daerah, dan pendapatan daerah. Pajak daerah merupakan iuran wajib yang dipaksakan berdasarkan peraturan perundang-undangan yang berlaku (Dewi \& Sri Budhi, 2018).

Berlakunya Undang-undang Nomor 6 Tahun 1983 tanggal 31 Desember 1983 tentang Ketentuan Umum dan Tata Cara Perpajakan menjadi salah satu tujuan untuk meningkatkan sistem perpajakan yang efektif dan efisien. Peningkatan penerimaan pajak dapat mempengaruhi pembangunan di seluruh Indonesia. Beberapa hal yang dilakukan oleh pemerintah untuk meningkatkan pajak daerah yaitu mampu menciptakan prosedur perpajakan yang memudahkan wajib pajak dalam membayar pajak. Selain itu, peningkatan pajak daerah dapat dicapai dari peningkatan pelayanan publik yang diberikan oleh pemerintah daerah. Peningkatan penerimaan pajak daerah akan berdampak pada peningkatan pertumbuhan ekonomi serta pembangunan daerah (Saragih, 2018).

Pertumbuhan ekonomi yang meningkat dan distribusi pendapatan yang lebih merata dapat meningkatkan kesejahteraan masyarakat. Peningkatan kesejateraan masyarakat merupakan salah satu tujuan dari pembangunan ekonomi daerah. Pertumbuhan ekonomi suatu daerah dapat diukur melalui laju pertumbuhan PDRB yang ada di masing-masing daerah. Pertumbuhan ekonomi sebuah negara yang cepat dapat mencerminkan kemakmuran masyarakat yang tinggi. Selain itu, pertumbuhan ekonomi dapat menunjukkan keadaan pendapatan masyarakat di daerah (Rahman \& Chamelia, 2015).

Indeks Pembangunan Manusia (IPM) merupakan salah satu indikator yang dapat mengukur perkembangan kualitas sumber daya manusia. IPM Kabupaten dan Kota di Jawa Tengah ratarata meningkat setiap tahunnya di lima tahun terakhir. Berikut adalah data tentang peningkatan kesejahteraan masyarakat dilihat dari Indeks Pembangunan Manusia (IPM) lima tahun terakhir dari 2015-2019 di Kabupaten dan Kota Jawa Tengah 


\section{P ISSN 2622-7177 \\ [ACCOUNTING GLOBAL JOURNAL] \\ E ISSN 2623-1778}

Tabel 1. IPM Kabupaten dan Kota di Jawa Tengah Tahun 2015-2019

\begin{tabular}{|r|l|rrrrr|}
\hline No & Kabupaten/Kota & \multicolumn{5}{|c|}{ Tahun } \\
\cline { 2 - 6 } & & 2015 & 2016 & 2017 & 2018 & 2019 \\
\hline 1 & Kabupaten Cilacap & 67.77 & 68.6 & 68.9 & 69.56 & 69.98 \\
3 & Kabupaten Banyumas & 69.89 & 70.49 & 70.75 & 71.3 & 71.96 \\
4 & Kabupaten Purbalingga & 67.03 & 67.48 & 67.72 & 68.41 & 68.99 \\
5 & Kabupaten Banjarnegara & 64.73 & 65.52 & 65.86 & 66.54 & 67.34 \\
6 & Kabupaten Kebumen & 66.87 & 67.41 & 68.29 & 68.8 & 69.6 \\
7 & Kabupaten Purworejo & 70.37 & 70.66 & 71.31 & 71.87 & 72.5 \\
8 & Kabupaten Magelang & 65.7 & 66.19 & 66.89 & 67.81 & 68.27 \\
9 & Kabupaten Boyolali & 71.13 & 67.85 & 68.39 & 69.11 & 69.87 \\
10 & Kabupaten Klaten & 73.81 & 73.97 & 74.25 & 74.79 & 75.29 \\
11 & Kabupaten Sukoharjo & 74.53 & 75.06 & 75.56 & 76.07 & 76.84 \\
12 & Kabupaten Wonogiri & 67.76 & 68.23 & 68.66 & 69.37 & 69.98 \\
13 & Kabupaten Karanganyar & 74.26 & 74.9 & 75.22 & 75.54 & 75.89 \\
14 & Kabupaten Sragen & 71.1 & 71.43 & 72.4 & 72.96 & 73.43 \\
15 & Kabupaten Grobogan & 68.05 & 68.52 & 68.87 & 69.32 & 69.86 \\
16 & Kabupaten Blora & 66.22 & 66.61 & 67.52 & 67.95 & 68.65 \\
17 & Kabupaten Rembang & 68.18 & 68.6 & 68.95 & 69.46 & 70.15 \\
18 & Kabupaten Pati & 68.51 & 69.03 & 70.12 & 70.71 & 71.35 \\
19 & Kabupaten Kudus & 72.72 & 72.94 & 73.84 & 74.58 & 74.94 \\
20 & Kabupaten Jepara & 70.02 & 70.25 & 70.79 & 71.38 & 71.88 \\
21 & Kabupaten Demak & 69.75 & 70.1 & 70.41 & 71.26 & 71.87 \\
22 & Kabupaten Semarang & 71.89 & 72.4 & 73.2 & 73.61 & 74.14 \\
23 & Kabupaten Temanggung & 67.07 & 67.6 & 68.34 & 68.83 & 69.56 \\
24 & Kabupaten Kendal & 69.57 & 70.11 & 70.62 & 71.28 & 71.97 \\
25 & Kabupaten Batang & 65.46 & 66.38 & 67.35 & 67.86 & 68.42 \\
26 & Kabupaten Pekalongan & 67.4 & 67.71 & 68.4 & 68.97 & 69.71 \\
27 & Kabupaten Pemalang & 63.7 & 64.17 & 65.04 & 65.67 & 66.32 \\
28 & Kabupaten Tegal & 65.04 & 65.84 & 66.44 & 67.33 & 68.24 \\
29 & Kabupaten Brebes & 63.18 & 63.98 & 64.86 & 65.68 & 66.12 \\
30 & Kota Magelang & 76.39 & 77.16 & 77.84 & 78.31 & 78.8 \\
31 & Kota Surakarta & 80.14 & 80.76 & 80.85 & 81.46 & 81.86 \\
32 & Kota Salatiga & 80.96 & 81.14 & 81.68 & 82.41 & 83.12 \\
33 & Kota Semarang & 80.23 & 81.19 & 82.01 & 82.72 & 83.19 \\
34 & Kota Pekalongan & 72.69 & 73.32 & 73.77 & 74.24 & 74.77 \\
35 & Kota Tegal & 72.96 & 73.55 & 73.95 & 74.44 & 74.93 \\
\hline
\end{tabular}

Sumber: BPS Jawa Tengah, diolah

Jika dilihat dari Tabel 1, IPM 35 Kabupaten dan Kota di Jawa Tengah mengalami peningkatan yang positif pada tahun 2015-2019. Kota Semarang menjadi kota yang 
mempunyai IPM tertinggi di tahun 2016-2019 yaitu sebesar 81.19 pada tahun 2016, 82.01 pada tahun $2017,82.72$ pada tahun 2018, dan 83.19 pada tahun 2019. Pada tahun 2015 IPM tertinggi ada di Kota Salatiga yaitu sebesar 80.96. Berdasarkan latar belakang di atas, peneliti tertarik untuk melakukan penelitian dengan judul "Pengaruh Pajak, Retribusi Daerah, dan PDRB terhadap Kesejahteraan Masyarakat (Studi pada Kabupaten dan Kota di Jawa Tengah)". Penelitian ini berfokus pada kesejahteraan masyarakat yang diukur dengan Indeks Pembangunan Manusia pada tahun 2015-2019.

\subsection{Rumusan Masalah}

Rumusan masalah dalam penelitian ini melihat dari latar belakang di atas yaitu:

1. Apakah pajak daerah berpengaruh terhadap kesejahteraan masyarakat?

2. Apakah retribusi daerah berpengaruh terhadap kesejahteraan masyarakat?

3. Apakah PDRB berpengaruh terhadap kesejahteraan masyarakat?

\subsection{Tujuan Penelitian}

Tujuan dari penelitian ini yaitu berdasarkan rumusan masalah di atas yaitu:

1. Apakah pajak daerah berpengaruh terhadap kesejahteraan masyarakat?

2. Apakah retribusi daerah berpengaruh terhadap kesejahteraan masyarakat?

3. Apakah PDRB berpengaruh terhadap kesejahteraan masyarakat?

\section{TINJAUAN PUSTAKA}

\subsection{Pajak daerah dan Retribusi Daerah}

Undang-Undang Nomor 28 Tahun 2009 tentang pajak dan retribusi daerah menyebutkan bahwa pajak daerah dan retribusi daerah merupakan salah satu sumber pendapatan daerah yang bergunan untuk membiayai pelaksanaan pemerintah daerah dalam rangka meningkatkan pelayanan kepada masyarakat dan kemandirian daerah. Pajak daerah adalah kontribusi wajib kepada daerah yang terutang oleh orang pribadi atau badan yang bersifat memaksa berdasarkan Undang-Undang dengan tidak mendapatkan imbalan secara langsung dan digunakan untuk keperluan daerah bagi sebesar-besarnya kemakmuran rakyat (UndangUndang, 2009). Retribusi daerah adalah pungutan daerah sebagai pembayaran atas jasa atau 
pemberian izin tertentu yang khusus disediakan dan/atau diberikan oleh Pemerintah Daerah untuk kepentingan orang pribadi atau badan.

Pajak daerah dan retribusi daerah di Jawa Tengah mengalami kenaikan dan penurunan selama lima tahun terakhir. Berikut tabel yang dapat dilihat dari segi pajak daerah dan retribusi daerah. Di tahun 2017, pajak daerah mengalami penurunan dari tahun 2016 menjadi Rp 10.166.892.000.000. Namun, pajak daerah di tahun 2018 mengalami peningkatan kembali sebesar Rp 10.840.111.435.000. Kenaikan dan penurunan pajak daerah dan retribusi daerah di Jawa Tengah tahun 2015-2019.

Tabel 2. Pajak Daerah dan Retribusi Daerah Propinsi Jawa Tengah Tahun 2015-2019

\begin{tabular}{|c|c|c|c|}
\hline No & Tahun & Pajak Daerah & Retrubusi Daerah \\
\hline 1 & 2015 & 10.512 .318 .175 .000 & 92.871 .359 .549 \\
\hline 2 & 2016 & 12.054 .424 .421 .000 & 96.570 .884 .000 \\
\hline 3 & 2017 & 10.166 .892 .000 .000 & 99.766 .182 .000 \\
\hline 4 & 2018 & 10.840 .111 .435 .000 & 105.103 .744 .000 \\
\hline 5 & 2019 & 11.712 .670 .654 .000 & 126.080 .182 .000 \\
\hline
\end{tabular}

Sumber: BPS Propinsi Jawa Tengah

\subsection{Produk Domestik Regional Bruto (PDRB)}

Produk Domestik Regional Bruto merupakan indicator untuk mengetahui konsisi ekonomi suatu daerah. Nilai PDRB menjelaskan mengenai kemampuan daerah dalam mengelola atau memanfaatkan sumber daya. PDRB adalah jumlah nilai tambah yang dihasilkan untuk seluruh wilayah usaha dan jasa dalam suatu wilayah (Rahman \& Chamelia, 2015).

PDRB atas dasar harga konstan menggambarkan nilai tambah barang dan jasa dengan perhitungan harga barang berlaku pada satu tahun tertentu sebagai dasar. PDRB atas dasar harga konstan digunakan untuk mengetahui pertumbuhan ekonomi dari tahun ke tahun. PDRB atas dasar harga berlaku menggambarkan nilai tambah barang dan jasa yang perhitungannya dari harga berlaku setiap tahunnya. PDRB atas dasar harga berlaku digunakan untuk melihat pergeseran dan struktur ekonomi (Indradewa \& Natha, 2015)

\subsection{Kesejahteraan Masyarakat}

Pendapatan daerah berhubungan dengan tingkat kesejahteraan masyarakat. Kesejahteraan masyarakat dapat dinilai menggunakan Indeks Pembangunan Manusia (IPM). Ada tiga aspek 
dalam menentukan ukuran IPM untuk menunjukkan tingkat kesejahteraan masyarakat, yaitu pendidikan, Kesehatan, dan pendapatan (Irviani, Jatiningrum, \& Kasmi, 2019).

Indeks Pembangunan Manusia (IPM) atau disebut dengan Human Development Index (HDI) ditetapkan oleh Perserikatan Bangsa-Bangsa (PBB) sebagai ukuran standar pembangunan manusia. IPM digunakan sebagai penentu suatu negara termasuk dalam negara maju ataupun negara berkembang. IPM mengukur capaian pembangunan manusia berbasis sejumlah komponen dasar kualitas hidup (Trianggara, Rahmawati, \& Yasin, 2016).

\subsection{Pengaruh Pajak Daerah dan Retribusi Daerah terhadap Kesejahteraan Masyarakat}

Irviani et al. (2019) melakukan penelitian tentang pengaruh pendapatan daerah dan kinerja keuangan terhadap pertumbuhan ekonomi dan kesejahteraan masyarakat di Kabupaten/Kota Provinsi Lampung. Hasil penelitiannya yaitu seluruh variabel pendapatan daerah kecuali retribusi daerah dan masing-masing variabel kinerja ekonomi berpengaruh signifikan terhadap tingkat kesejahteraan masyarakat (IPM) di Kapubaten/Kota Provinsi Lampung. Penelitian yang dilakukan oleh Dewi \& Sri Budhi (2018) tentang analisis pengaruh pajak daerah, retribusi daerah terhadap tenaga kerja dan pertumbuhan ekonomi di Kota Palangkaraya yaitu pajak daerah dan retribusi daerah berpengaruh positif dan signifikan terhadap pertumbuhan ekonomi daerah dalam rangka untuk meningkatkan kesejahteraan masyarakat.

Saragih (2018) melakukan penelitian berjudul An Analysis of Local Taxes Reveneu's Effect on Human Development Index. Hasil penelitiannya yaitu 34 provinsi di Indonesia pada periode 2013-2016, penerimaan pajak daerah berpengaruh positif dan signifikan terhadap indeks pembangunan manusia. Berdasarkan hasil penelitian terdahulu, hipoteses dalam penelitian dapat dirumuskan sebagai berikut.

$\mathrm{H}_{1}$ : Pajak daerah berpengaruh signifikan terhadap kesejahtraan masyarakat.

$\mathrm{H}_{2}$ : Retribusi daerah tidak berpengaruh signifikan terhadap kesejahteraan masyarakat 


\subsection{Pengaruh PDRB terhadap kesejahteraan masyarakat}

Muliza, Zulham, \& Seftarita (2017) melakukan penelitian tentang Ananlisis Pengaruh Belanja Pendidikan, Belanja Kesehatan, Tingkat Kemiskinan dan PDRB terhadap IPM di Provinsi Aceh hasilnya yaitu PDRB berpengaruh negatif dan signifikan terhadap IPM di kabupaten/kota Provinsi Aceh. Hasil tersebut menunjukkan tingkat kemiskinan yang menurun dapat meningkatkan IPM. Selain itu, Bhakti, Istiqomah, \& Suprapto, (2017) melakukan penelitian berjudul Analisis Faktor-Faktor yang Mempengaruhi Indeks Pembangunan Manusia di Indonesia Periode 2008-2012. Hasil penelitian tersebut yaitu PDRB berpengaruh positif terhdap IPM. Berdasarkan hasil penelitian terdahulu, hipotesis dalam penelitian ini dapat dirumuskan sebagai berikut.

$\mathrm{H}_{3}$ : PDRB berpengaruh signifikan terhadap kesejahteraan masyarakat.

\subsection{Kerangka Teoritis}

Berdasarkan penjelasan yang telah diuraikan, maka penelitian ini akan menelliti tentang pengaruh pajak daerah, retribusi daerah dan PDRB terhadap kesejahteraan masyarakat/ berikut merupakan kerangka teoritis dalam penelitian ini.

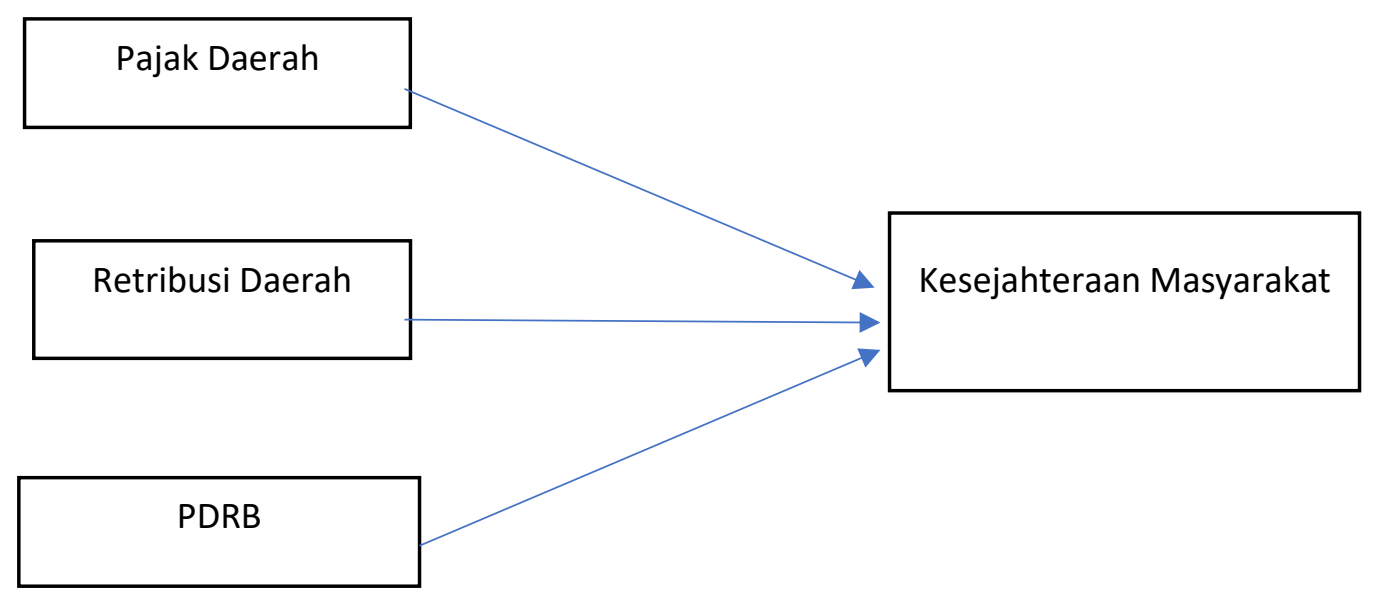

\section{METODE PENELITIAN}

\subsection{Data Penelitian}

Data yang digunakan dalam penelitian ini adalah data sekunder. Data sekunder didapatkan dari dokumen resmi Badan Pusat Statistik (BPS) Provinsi Jawa Tengah. Data di yang digunakan yaitu data kuantitatif pada rentang waktu antara tahun 2015-2019. Penelitian ini 
menggunakan populasi dari seluruh kabupaten/kota di Jawa Tengah berjumlah 29 kabupaten dan 6 kota.

\subsection{Variabel Penelitian dan Definisi Operasional}

Variabel Dependen dalam penelitian ini yaitu kesejahteraan masyarakat yang diukur dari nilai IPM. Data IPM Provinsi Jawa Tengah didapat dari BPS yang disajikan dalam presentase, Variabel independen dalam penelitian ini yaitu pajak daerah, teribusi daerah, dan PDRB. data pajak daerah dan retribusi daerah didapatkan dari Anggaran Pendapatan dan Belanja Daerah (APBD) di Provinsi Jawa Tengah yag bersumber di website resmi BPS Jawa Tengah dan di website www.djpk.kemenkeu.go.id. Data PDRB yang digunakan yaitu PDRB harga konstan. PDRB disajikan dalam milyar rupiah.

\subsection{Pengujian Hipotesis}

Penelitian ini menggunakan model analisis regresi berganda dalam uji hipotestnya. Pengujian tersebut untuk memprediksi kekuatan pengaruh variabel independent terhadap variabel independen. Persamaan regresinya yaitu:

\section{$\mathbf{K M}=\alpha+\boldsymbol{\beta}_{1} \mathbf{X}_{1}+\boldsymbol{\beta}_{2} \mathbf{X}_{2}+\boldsymbol{B}_{3} \mathbf{X}_{3}+e$}

Keterangan:

TKM= Tingkat Kesejahteraan Masyarakat,

$\alpha=$ Konstanta,

$\beta=$ Slope atau koefisien regresi atau intersep,

$\mathrm{X}_{1}=\mathrm{PAD}$,

$\mathrm{X}_{2}=$ Dana bagi hasil $(\mathrm{DBH})$,

$\mathrm{X}_{3}=$ Dana Alokasi Umum (DAU),

\subsection{Teknik Analisis}

\section{Uji t}

Uji t berguna untuk membuktikan bahwa variabel bebas secara inidvidu berpengaruh terhadap variabel terikat. Uji t juga digunakan untuk mengeatuhi makna dari koefisien parsial. Uji t tersebut dilakukan dengan cara membandingkan nilai statistic t dengan titik kritis menurut tabel. Apabila 
nilai statistic thasil lebih tinggi dibandingkan dengan nilai ttabel, maka hipotesis alternative diterima.

Ho: $\beta=0$, variabel bebas tidak ada pengaruh parsial terhadap variabel terikat

Ha: $\beta>0$, variabel bebas ada pengaruh positif dan signifikan secara parsial terhadap variabel terikat.

Adapun kriteria pada uji t yaitu taraf signifikan sebesar $0,05 \%$, apabila $\mathrm{t}_{\text {hitung }}<\mathrm{t}_{\text {tabel }}$ maka Ho diterima Ha ditolak, apabila $t_{\text {hitung }}>\mathrm{t}_{\text {tabel }}$ maka Ho ditolak Ha diterima.

\section{Uji F}

Uji F digunakan untuk menunjukkan apakah semua variabel bebas yang dimasukkan dalam model mempunyai pengaruh secara bersama-sama terhadap variabel terikat. Uji F dilakukan dengan memabandingkan antara nilai kritis $\mathrm{F}_{\text {tabel }}$ dengan nilai $\mathrm{F}_{\text {hitung }}$ yang terdapat pada tabel Analysis of Variance dari hasil perhitungan. Apabila $\mathrm{F}_{\text {hitung }}<\mathrm{F}_{\text {tabel, }}$, maka Ho ditolak sehingga dapat dikatakan bahwa variabel bebas dari regresi dapat menerangkan variabel terikat secara serentak. Apabila $\mathrm{F}_{\text {hitung }}<\mathrm{F}_{\text {tabel, }}$, maka Ho diterima sehingga variabel bebas tidak perlu menjelaskan variabel terkait.

\section{Koefisien Determinasi $\left(\mathbf{R}^{2}\right)$}

Koefisien determinasi digunakan untuk mengeahui besarnya kontribusi variabel bebas dan variabel terikat. Hasil perhitungan $\mathrm{R}^{2}$ digunakan untuk mengukur ketepatan yang paling baik dari analisis regresi linier berganda.

- Apabila $\mathrm{R}^{2}$ mendekati 1, maka model semakin kuat dalam menjelaskan variabel bebas terhadap variabel terikat.

- Apabila $\mathrm{R}^{2}$ mendekati 0, maka model semakin lemah dalam menjelaskan variabel bebas terhadap variabel terikat.

\section{HASIL DAN PEMBAHASAN}

\subsection{Statistik Deskriptif}

Berdasarkan data yang diolah didapatkan deskripsi statistic yang dapat dilihat pada tabel berikut. 
Tabel 3. Descriptive Statistic

\begin{tabular}{|l|r|r|c|}
\hline \multicolumn{4}{|c|}{ Descriptive Statistic } \\
\hline & \multicolumn{1}{|c|}{ Mean } & \multicolumn{1}{c|}{ Std. Deviation } & N \\
\hline IPM & 712,129 & 451,066 & 175 \\
\hline Pajak_Daerah & 106153389716,86 & $178,466,561,784,387$ & 175 \\
\hline Retribusi_Daerah & 25155944284,69 & $26,234,663,248,813$ & 175 \\
\hline PDRB & 25652019,66 & $23,963,515,940$ & 175 \\
\hline
\end{tabular}

Sumber : Data yang diolah SPSS

Berdasarkan tabel di atas, $\mathrm{N}$ menyatakan jumlah data yang valid. Valid artinya data yang ada atau terisi. Jumlah data yang valid sebanyak 175. Mean atau nilai rata-rata untuk IPM sebesar 712,129; pajak daerah sebesar 106153389716,86; retribusi daerah sebesar 25155944284,69; dan PDRB sebesar 25652019,66. Standar deviation menyatakan simpangan baku yaitu akar dari variansi. Hasil dari olah data penelitian menunjukkan nilai standar deviation untun IPM sebesar 451,066; pajak daerah sebesar 178,466,561,784,387; retribusi daerah sebesar 26,234,663,248,813; dan PDRB sebesar 23,963,515,940

\subsection{Uji Asumsi Klasik}

\section{Uji Multikolinieritas}

Uji Multikolinieritas bertujuan untuk menguji model regresi yang ditemukan apakah ada korelasi antar variabel bebas. Berikut adalah hasil output SPSS.

Tabel 4. Uji Multikolinieritas

Sumber : Data yang diolah SPSS

\begin{tabular}{|l|r|c|}
\hline \multirow{2}{*}{ Model } & \multicolumn{2}{c|}{ Collinearity Statistics } \\
\cline { 2 - 3 } & Tolerance & \multicolumn{1}{c|}{ VIF } \\
\hline Pajak daerah & 0,118 & 8,484 \\
\hline Retribusi Daerah & 0,159 & 6,277 \\
\hline PDRB & 0,390 & 2,566 \\
\hline
\end{tabular}

Berdasarkan hasil olah data di atas menunjukkan bahwa ketiga varibel independen memiliki nilai lebih dari 0,10 dan memiliki nilai VIF kurang dari 10. Jadi kesimpulannya ketiga variabel tersebut tidak terjadi multikolinieritas antar variabel bebas dalam model regresi. 


\section{Uji Heterokedastisitas}

Uji Heterokedastisitas untuk menguji apakah terjadi ketidaksamaan variasi dari residual satu pengamatan ke pengamatan yang lain dalam model regresi. Berikut adalah hasil dari output SPSS.

Tabel 5. Uji Heterokesdasitas

\begin{tabular}{|c|c|c|c|c|c|c|}
\hline & \multirow{2}{*}{ Model } & \multicolumn{2}{|c|}{$\begin{array}{l}\text { Unstandardized } \\
\text { Coefficients }\end{array}$} & \multirow{2}{*}{$\begin{array}{c}\begin{array}{c}\text { Standardized } \\
\text { Coefficients }\end{array} \\
\text { Beta }\end{array}$} & \multirow{2}{*}{$\mathrm{t}$} & \multirow{2}{*}{ Sig. } \\
\hline & & B & $\begin{array}{l}\text { Std. } \\
\text { Error }\end{array}$ & & & \\
\hline \multirow{4}{*}{1} & (Constant) & 71,257 &, 554 & & 128,592 &, 000 \\
\hline & Pajak_Daerah & $2.63 \mathrm{E}-08$ & ,000 & 1,042 & 5,533 & ,000 \\
\hline & Retribusi_Daerah & $-7.11 \mathrm{E}-08$ & ,000 &,- 414 & $-2,552$ &, 012 \\
\hline & PDRB & $-4.10 \mathrm{E}-05$ &, 000 &,- 218 & $-2,103$ &, 037 \\
\hline
\end{tabular}

Sumber : Data yang diolah SPSS

Dasar pengambilan keputusan dalam uji heterokedastisitas dengan menggunakan uji glejser yaitu jika nilai signifikansi lebih besar dari 0,05 , kesimpulannya tidak terjadi gejala heterokedastisitas dalam model regresi, dan sebaliknya. Berdasarkan data di atas,variabel retribusi daerah dan variabel PDRB mempunyai nilai signifikansi 0,012 dan 0,037 berarti kedua variabel tersebut terbebas dari gejala heterokedastisitas. Variabel pajak daerah mempunyai nilai signifikansi kurang dari 0,05 yaitu sebesar 0,000 berarti variabel pajak daerah terjadi gejala heterokedastisitas.

\subsection{Uji Statistik t}

Tabel 6. Uji Statistik t

\begin{tabular}{|c|c|c|c|c|c|c|}
\hline & \multirow{2}{*}{ Model } & \multicolumn{2}{|c|}{$\begin{array}{c}\text { Unstandardized } \\
\text { Coefficients } \\
\end{array}$} & \multirow{2}{*}{$\begin{array}{c}\text { Standardized } \\
\text { Coefficients } \\
\text { Beta }\end{array}$} & \multirow{2}{*}{$\mathrm{t}$} & \multirow{2}{*}{ Sig. } \\
\hline & & B & $\begin{array}{l}\text { Std. } \\
\text { Error }\end{array}$ & & & \\
\hline \multirow{4}{*}{1} & (Constant) & 71,257 & ,554 & & 128,592 &, 000 \\
\hline & Pajak_Daerah & $2.63 \mathrm{E}-08$ & ,000 & 1,042 & 5,533 &, 000 \\
\hline & Retribusi_Daerah & $-7.11 \mathrm{E}-08$ & ,000 &,- 414 & $-2,552$ & ,012 \\
\hline & PDRB & $-4.10 \mathrm{E}-05$ & 000 &,- 218 & $-2,103$ & 037 \\
\hline
\end{tabular}

Sumber : Data diolah SPSS 
Uji statistik t bertujuan untuk mengintepretasikan koefisien parameter variable independent. Variable dikatakan signifikan terhadap variable dependen jika nilai signifikansi di bawah 0,05. Berdasarkan tabel di atas, ketiga variabel independen mempunyai nilai signifikan terhadap variabel dependen. Nilai variabel pajak daerah sebesar 0,000; nilai variabel retribusi daerah sebesar 0,12; dan nilai variabel PDRB sebesar 0,37.

\subsection{Uji Statistik F}

Tabel 7. Uji Statistik F

\begin{tabular}{|c|l|r|r|r|r|c|}
\hline \multicolumn{2}{|c|}{ Model } & $\begin{array}{c}\text { Sum of } \\
\text { Squares }\end{array}$ & \multicolumn{1}{c|}{ df } & $\begin{array}{c}\text { Mean } \\
\text { Square }\end{array}$ & F & Sig. \\
\hline \multirow{3}{*}{1} & Regression & $1,009,160$ & 3 & 336,387 & 22,727 &, $000^{\mathrm{b}}$ \\
\cline { 2 - 7 } & Residual & $2,531,047$ & 171 & 14,801 & & \\
\cline { 2 - 7 } & Total & $3,540,207$ & 174 & & & \\
\hline
\end{tabular}

Uji statistic F pada dasarnya menunjukkan apakah semua variable independen yang dimasukkan dalam model mempunyai pengaruh secara bersama-sama atau simultan terhadap variable dependen. Pengujian hipotesis ini sering disebut pengujian signifikansi keseluruhan terhadap garis regresi yang ingin menguji apakah variable dependen secara linier berhubungan dengan variable independen.

Berdasarkan tabel diatas yang dapat dilhat dari tabel ANOVA atau $\mathrm{F}$ test diperoleh nilai $\mathrm{F}$ hitung sebesar 22,727 dengan probabilitas 0,000. Oleh karena probabilitas lebih kecil dari 0,05 maka dapat disimpulkan bahwa koefisien regresi variable independen tidak sama dengan nol. Hal tersebut membuktikan bahwa variable independen pajak derah, retribusi daerah, dan PDRB secara simultan berpengaruh terhadap tingkat kesejahteraan masyarakat.

\subsection{Koefisien Determinasi (R Square)}

Uji koefisien determinasi menunjukkan bahwa semakin besar nilai koefisien determinan maka semakin besar pula pengaruh variabel independen terhadap variabel bebas. Berikut merupakan hasil uji koefisien determinasi R Square. 
Tabel 8. Uji Koefisien Determinasi R Square

\begin{tabular}{|c|c|c|c|c|c|c|c|c|c|c|}
\hline \multirow[b]{2}{*}{ Model } & \multirow[b]{2}{*}{$\mathrm{R}$} & \multirow[b]{2}{*}{$\begin{array}{c}\mathrm{R} \\
\text { Square }\end{array}$} & \multirow[b]{2}{*}{$\begin{array}{c}\text { Adjusted } \\
\text { R } \\
\text { Square }\end{array}$} & \multirow{2}{*}{$\begin{array}{c}\text { Std. } \\
\text { Error of } \\
\text { the } \\
\text { Estimate }\end{array}$} & \multicolumn{5}{|c|}{ Change Statistics } & \multirow[b]{2}{*}{$\begin{array}{l}\text { Durbin- } \\
\text { Watson }\end{array}$} \\
\hline & & & & & $\begin{array}{c}\mathrm{R} \\
\text { Square } \\
\text { Change }\end{array}$ & $\begin{array}{c}\text { F } \\
\text { Change }\end{array}$ & df1 & df2 & $\begin{array}{c}\text { Sig. F } \\
\text { Change }\end{array}$ & \\
\hline 1 &, $534^{\mathrm{a}}$ & ,285 & ,273 & 384,726 & 285 & 22,727 & 3 & 17 &, 000 & 1,179 \\
\hline
\end{tabular}

Sumber : Data diolah SPSS

Berdasarkan tabel di atas, nilai koefisien determinasi (Adjusted $R$ Square) sebesar 0,273. Hal tersebut menunjukkan bahwa ketiga variabel independen yaitu pajak daerah, retribusi daerah, dan PDRB secara simultan memberikan pengaruh sebesar 27,3\% terhadap kesejahteraan masyarakat di Jawa tengah pada tahun 2015-2019. Selebihnya 72,7\% merupakan faktorfaktor lain di luar variabel penelitian.

\subsection{Pembahasan}

Berdasarkan tabel 6, variabel pajak daerah berpengaruh signifikan terhadap kesejahteraan masyarakat di Jawa tengah. Hal tersebut selaras dengan penelitian Saragih, (2018) bahwa pemerintah daerah yang efektif dalam melaksanakan reformasi perpajakan daerah dapat mengoptimalkan ekstemsifikasi dan intensifikasi penerimaan pajak. Pengoptimalan tersebut dapat meningkatkan penerimaan pajak untuk kepentingan pembangunan daerah dan kesejahteraan masyarakat. Penelitian ini menggunakan data lima tahun sehingga dapat memberikan gambaran yang lebih umum mengenai pengaruh penerimaan pajak terhadap indeks pembangunan manusia.

Retribusi pajak daerah dalam penelitian ini berpengaruh signifikan terhadap kesejahteraan masyarakat. Hal tersebut tidak selaras dengan penelitian Dewi \& Sri Budhi, (2018) yang menyatakan retribusi daerah tidak berpengaruh pada pertumbuhan ekonomi yang berkesinambungan dengan kesejahteraan masyarakat. Berdasarkan hasil penelitian ini, retribusi daerah yang merupakan bagian dari pendapatan daerah dapat meningkatkan kesejahteraan masayarakat di Jawa Tengah.

PDRB dalam hasil penelitian ini berpengaruh signifikan terhadap kesejahteraan masyakarat. Hasil penelitian tersebut selaras Bhakti et al., (2017) yang menyatakan bahwa PDRB berpengaruh signifikan terhadap kesejahteraan masyarakat. Meningkatnya pertumbuhan 
ekonomi mengubah pola konsumsi karena peningkatan daya beli. Tingginya daya beli masyarakat akan meningkatkan IPM karena daya beli masyarakat merupakan salah satu indikator komposit dalam IPM disebut indikator pendapatan.

\section{KESIMPULAN}

Berdasarkan hasil penelitian dan pembahasan di atas, penelitian ini dapat ditarik kesimpulan yaitu ketiga variabel independen; pajak daerah, retribusi daerah dan PDRB berpengaruh signifikan terhadap kesejahteraan masyarakat di kabupaten/kota Propinsi Jawa Tengah. APBD yang digunakan secara optimal dapat meningkatkan pendapatan daerah termasuk penerimaan pajak daerah dan retribusi daerah yang berkesinambungan dengan kesejahteraan masyarakat. Selain itu, peningkatkan PDRB di Jawa Tengah dapat meningkatkan kesejahteraan masyarakat.

\section{KETERBATASAN DAN SARAN}

\section{Keterbatasan Penelitian}

Penelitian ini hanya dapat menjelaskan kondisi khusus di Propinsi Jawa Tengah selama lima tahun yaitu periode 2015-2019. Variabel independent yang digunakan yaitu pajak daerah, retribusi daerah, dan PDRB hanya mampu menjelaskan 27,3\% pengaruh terhadap kesejahteraan masyarakat. Selebihnya $72,7 \%$ dijelaskan pada variabel lain diluar dari ketiga variabel diatas.

\section{Saran}

Saran yang diberikan untuk penelitian selanjutnya yaitu menggunakan variabel bebas lainnya yang berhubungan dengan penelitian terkait. Penelitian ini hanya berfokus pada daerah kabupaten/kota Jawa Tengah sehingga tidak dapat digeneralisir di daerah lainnya. Saran untuk pemerintah daerah yaitu pemerintah selalu mengoptimalkan APBD untuk kegiatan masyarakat sehingg pertumbuhan eknomi daerah dapat meningkat sejalan dengan meningkatnya kesejahteraan masyarakat. 


\section{DAFTAR PUSTAKA}

Bhakti, N. A., Istiqomah, I., \& Suprapto, S. (2017). Analisis Faktor-Faktor Yang Mempengaruhi Indeks Pembangunan Manusia Di Indonesia Periode 2008-2012. EKUITAS $\begin{array}{lllll}\text { (Jurnal Ekonomi } & \text { Dan } & \text { Keuangan), } & 18(4), & 452 .\end{array}$ https://doi.org/10.24034/j25485024.y2014.v18.i4.2162

Dewi, J. K., \& Sri Budhi, M. K. (2018). Analisis Pengaruh Pajak Daerah, Retribusi Daerah Terhadap Tenaga Kerja Dan Pertumbuhan Ekonomi Di Kota Palangka Raya Provinsi Kalimantan Tengah. E-Jurnal Ekonomi Dan Bisnis Universitas Udayana, 6, 1695. https://doi.org/10.24843/eeb.2018.v07.i06.p08

Indradewa, I., \& Natha, K. (2015). Pengaruh Inflasi, Pdrb Dan Upah Minimum Terhadap Penyerapan Tenaga Kerja Di Provinsi Bali. E-Jurnal Ekonomi Pembangunan Universitas Udayana, 4(8), 923-950.

Irviani, R., Jatiningrum, C., \& Kasmi, K. (2019). Pengaruh Pendapatan Daerah Dan Kinerja Keuangan Terhadap Pertumbuhan Ekonomi Dan Kesejahteraan Masyarakat Pada Kabupaten/Kota Provinsi Lampung. AKUNTABILITAS: Jurnal Penelitian Dan Pengembangan Akuntansi, 11(1), 1-14. https://doi.org/10.29259/ja.v11i1.8925

Muliza, M., Zulham, T., \& Seftarita, C. (2017). Analisis Pengaruh Belanja Pendidikan, Belanja Kesehatan, Tingkat Kemiskinan Dan Pdrb Terhadap Ipm Di Provinsi Aceh. Jurnal Perspektif Ekonomi Darussalam, 3(1), 51-69. https://doi.org/10.24815/jped.v3i1.6993

Rahman, Y. A., \& Chamelia, A. L. (2015). Faktor - Faktor Yang Mempengaruhi Pdrb Kabupaten / Kota Jawa Tengah Tahun 2008-2012. Jejak, 8(1), 88-99. https://doi.org/10.15294/jejak.v8i1.3857

Riduansyah, M. (2003). Kontribusi Pajak Daerah Dan Retribusi Daerah Terhadap Pendapatan Asli Daerah (Pad) Dan Anggaran Pendapatan Dan Belanja Daerah (Apbd) Guna Mendukung Pelaksanaan Otonomi Daerah (Studi Kasus Pemerintah Daerah Kota Bogor). Makara Human Behavior Studies in Asia, 7(2), 49. https://doi.org/10.7454/mssh.v7i2.51

Saragih, A. H. (2018). An Analysis of Local Taxes Revenue's Effect on Human Development Index. Jurnal Economia, 14(2), 197-211. https://doi.org/10.21831/economia.v14i2.21595

Trianggara, N., Rahmawati, R., \& Yasin, H. (2016). Pemodelan Indeks Pembangunan Manusia Menggunakan Spatial Panel Fixed Effect (Studi Kasus: Indeks Pembangunan Manusia Propinsi Jawa Tengah 2008 - 2013). Jurnal Gaussian, 5(1), 173-182.

Undang_Undang. UNDANG-UNDANG REPUBLIK INDONESIA NOMOR 28 TAHUN 2009 Tentang Pajak Daerah dan Retribusi Daerah (2009). https://doi.org/10.1017/CBO9781107415324.004 